\section{Groundwater Quality and Human Health Risk Assessment Related to Groundwater Consumption in an Giang Province}

\begin{abstract}
Groundwater is one of the main sources for water supply for domestic use, irrigation, aquaculture and industry. With rapidly increasing in human population groundwater becomes more important for social and economic activities. This study is to evaluate the quality of groundwater using data from the eight monitoring wells over the period of 2009-2016. Human health risk was assessed for the population consuming groundwater contaminating arsenic. The findings indicated that groundwater wells in An Giang province were contaminated with microorganisms. The total dissolved solids (TDS) and hardness in Phu Tan and Cho Moi wells were significant higher than permissible level (QCVN 09-MT:2015/ BTNMT). In addition, groundwater wells in some small islands of An Giang were seriously contaminated with organic matters and arsenic. The mean arsenic concentration was up to $0.55 \pm 1.21 \mathrm{mg} / \mathrm{L}$. Estimation of carcinogenic risk for human population showed that the cancer risks ranged from medium $\left(8.66 \times 10^{-4}\right)$ to high $\left(8.26 \times 10^{-2}\right)$ for both children and adults. Alternative water supply sources should be offered for the population at risk. Regular health check is essential for local people in the arsenic contaminated groundwater.
\end{abstract}

Keywords: Carcinogenic risk; Groundwater; Arsenic; Health risk assessment

\section{Phan Kim Anh and Nguyen Thanh Giao*}

Department of Environmental Management, College of Environment and Natural Resources, Can Tho University, Vietnam

\section{*Corresponding author: \\ Nguyen Thanh Giao \\ ntgiao@ctu.edu.vn}

Department of Environmental Management, College of Environment and Natural Resources, Can Tho University, Vietnam

Citation: Anh PK, Giao NT (2018)

Groundwater Quality and Human Health Risk Assessment Related to Groundwater Consumption in an Giang Province. J Heavy Met Toxicity Dis Vol.3 No.2:4.

\section{Introduction}

An Giang province has large amount of groundwater that can be abstracted for serving for daily life, irrigation, aquaculture and industry. According to the Geological and Hydrological Federation, groundwater along Hau River and in the Northwest of the province can be exploited at the depth of $80-100 \mathrm{~m}$ and 250-300 $\mathrm{m}$ with the exploitable amounts reaching 30,000 $\mathrm{m}^{3} /$ day and potential reserve of $85,000 \mathrm{~m}^{3} /$ day [1]. In recent years, the major industrial activities, for example, processing of agricultural and fishery products and other sectors have also remarkably increased. In 2012, the agricultural production value of the province was over USD 353.2 million and tended to increase over years (up 2.3\% compared to 2011). The average Gross Domestic Product (GDP) growth rate was 8.63\% (20112015) [1]. The GDP growth statistics indicated that social and economic activities have been continuously increased, and this could lead to a large amount of wastes from agricultural, industrial activities and other sectors generated. The generated wastes have been dumped or improperly treated resulting in contaminating both surface and groundwater sources. Arsenic is natural substance and arsenic pollution in groundwater has become a great concern of An Giang province. Currently, 1,319 groundwater wells (accounting for $14.4 \%$ of the total numbers of groundwater wells) in An Giang have been discovered contaminated with arsenic at the concentration of greater than $50 \mu \mathrm{g} / \mathrm{L}$ while 756 wells with arsenic at concentration of greater than $10 \mu \mathrm{g} / \mathrm{L}$. Exposure to arsenic results in serious health problem, especially risk of cancer. This study aimed to assess the quality of groundwater at eight monitoring wells from 2009 to 2016 to identify trends in groundwater quality and to assess health risks for the population using arsenic-contaminated groundwater. The obtained results could provide additional data on the progress of groundwater quality and potential impacts associated with groundwater use. 


\section{Methodology}

\section{Sources of groundwater quality data}

Groundwater quality data from eight monitoring wells in the period 2009-2016 in An Giang province including temperature, $\mathrm{pH}$, total dissolved solids (TDS), hardness $\left(\mathrm{Ca}^{2+}\right.$ and $\left.\mathrm{Mg}^{2+}\right)$, nitrate $\left(\mathrm{NO}_{3}{ }^{-} \mathrm{N}\right)$, ammonium $\left(\mathrm{NH}_{4}^{+}-\mathrm{N}\right)$, coliforms, total iron (Fe) and arsenic (As) were collected from An Giang Department of Natural Resources and Environment. The locations of the monitoring wells were shown in Figure 1.

\section{Data analysis}

The variation in the groundwater quality parameters at the sampling sites was analyzed by one-way ANOVA using IBM SPSS statistics for Windows, version 20.0 (IBM Corp., Armonk, NY, USA); Duncan test was applied to compare the difference in groundwater quality parameters at a significance level of $5 \%(p<0.05)$. Groundwater quality parameters at monitoring wells were compared with the national technical regulation on ground water quality (QCVN 09-MT: 2015/BTNMT) to assess groundwater quality.

\section{Health risk assessment}

Health risk was investigated in this study to assess the potential carcinogenic endpoint associated with the use of arseniccontaminated groundwater. Health risk assessment was performed using the following steps:

Hazard identification: In this step, scientific and technical information relating to arsenic was collected, organized and evaluated to decide whether arsenic is likely to constitute a significant hazard to human health. The scientific data indicated that arsenic is a carcinogen.
Dose-response assessment: Since arsenic is a carcinogen, then the cancer slope factor (CSF) value is used for the health risk assessment process. SF was referenced from the risk assessment website (US EPA).

Exposure assessment: Exposure may be defined as the contact of a chemical, physical, or biological agent with the outer boundary of an organism. Exposure is usually defined as a function of time: An event that occurs when there is a contact boundary between a human and the environment with a contaminant of a specific concentration for an interval of time. In this study, arsenic is assumed via drinking pathway or ingestion. The chronic daily intake due to ingestion of groundwater could be calculated using Equation 1:

$$
C D I=\frac{C \times I R \times E F \times E D}{B W \times A T}
$$

Where $\mathrm{CDI}$ is chronic daily intake $(\mathrm{mg} / \mathrm{kg} \mathrm{BW}$-day); $\mathrm{C}$ is the concentration of arsenic ( $\mu \mathrm{g} / \mathrm{L}$ ); IR is Intake Rate (L/day); EF is Exposure Frequency (days/year); ED is Exposure Duration (years); BW is Body Weight (kg); and AT is Averaging Time (days).

Risk characterization: the most critical findings obtained from dose-response assessment and exposure assessment were combined. This step provides a description of the nature of the hazard and explicit accounting of the estimated degree of health risk.

Cancer risk was calculated by using Equation 2:

Risk $=\mathrm{CDI} \times \mathrm{SF}$

Where, SF is slope factor. For arsenic, the slope factor is $1.5 \mathrm{(mg} /$ $\left.\mathrm{kg}^{-d a y}\right)^{-1}$ (IRIS EPA). The acceptable health risk is one in million (1 $\times 10^{-6}$ ) meaning that one person is likely to develop cancer due to drinking to arsenic contaminated groundwater.

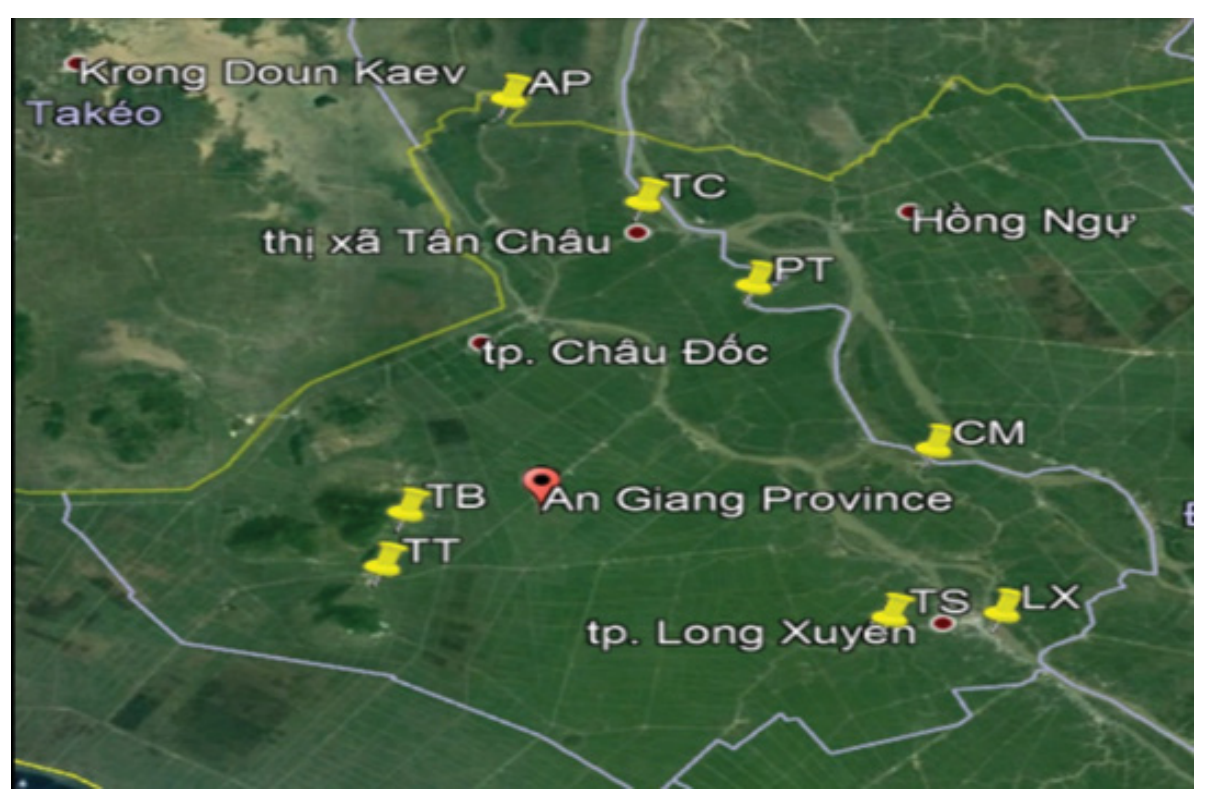

Figure 1 Locations of the groundwater monitoring wells. Notes that AP: An Phu station; TC: Tan Chau station; PT: Phu Tan station; CM: Cho Moi station; LX: Long Xuyen station; TS: Thoai Son station; TB: Tinh Bien station; TT: Tri Ton station. 
In this study, cancer risk of arsenic due to groundwater consumption is calculated for two groups of receptors including children and adults. The relevant information for estimating health risk was obtained from the previous studies [2-4] presented in Table 1.

\section{Results and Discussion}

\section{Groundwater quality in the monitoring wells}

The mean temperature in the groundwater in the period from 2009-2016 was $28.9 \pm 0.3^{\circ} \mathrm{C}$ (Figure 2a). The average temperatures and seasonal variation (dry and wet seasons) among monitoring wells were not significantly different $(p>0.05)$. The mean $p H$ at the monitoring sites ranged from $6.6 \pm 0.1$ to $7.1 \pm 0.2$ which was in the neutral range (Figure $\mathbf{2 b}$ ). The average total dissolved solids (TDS) has greatly fluctuated among monitoring wells (Figure 2c). The value of TDS at Cho Moi station was the highest $(4,516 \pm$ $2,768.7 \mathrm{mg} / \mathrm{L}$ ) which was statistically significant difference with those in the other monitoring wells $(p<0.05)$. High levels of TDS in groundwater are mainly due to the presence of sulfate, iron and occasionally arsenic. The values of TDS in Tan Chau, Thoai Son, and Tri Ton stations were in accordance with the National Technical Regulation on groundwater quality (QCVN 09-MT: 2015/BTNMT) while TDS values in the other stations including An Phu, Phu Tan, Cho Moi, Long Xuyen, Tinh Bien were higher than the regulation. The variation of TDS between seasons at each groundwater well was not significantly different.

The mean hardness in groundwater at the monitoring wells ranged from $197 \pm 130.59 \mathrm{mg} / \mathrm{L}$ to $1,272 \pm 681.21 \mathrm{mg} / \mathrm{L}$ (Figure 2d). Phu Tan station had the highest concentration of hardness at $1,272 \pm 681.21 \mathrm{mg} / \mathrm{L}$, followed by Cho Moi station at $1.246 \pm$ $297.73 \mathrm{mg} / \mathrm{L}$ and these values were significantly different from those found in the other monitoring stations $(p<0.05)$. The mean hardness of groundwater at An Phu, Phu Tan, Cho Moi, Long Xuyen were higher than the permitted hardness in groundwater according to QCVN 09-MT: 2015/BTNMT (500 mg/L). In the wells with high hardness concentration, groundwater quality is unsuitable for domestic use.

The mean level of nitrate $\left(\mathrm{NO}_{3}-\mathrm{N}\right)$ detected low in groundwater at all monitoring wells from 2009 to 2016, ranging from 0.09 \pm 0.13 to $0.99 \pm 0.98 \mathrm{mg} / \mathrm{L}$ (Figure 3a). The concentrations of nitrate were within the allowable limit. However, the nitrate concentrations were significantly different between wet season and dry season at Tinh Bien and Tri Ton stations. The average nitrate concentrations in groundwater at Tinh Bien and Tri Ton stations in dry season (March) and wet season (September) were $3.69 \pm 5.8 \mathrm{mg} / \mathrm{L}$ and $0.85 \pm 1.5 \mathrm{mg} / \mathrm{L}$ and $13.49 \pm 15.6 \mathrm{mg} / \mathrm{L}$ and $15.54 \pm 27 \mathrm{mg} / \mathrm{L}$, respectively. It was highly possible that during the dry period, nitrate (from agricultural practices) has been

Table 1 The relevant data for risk calculation.

\begin{tabular}{|c|c|c|c|c|c|}
\hline Receptors & $\begin{array}{c}\text { IR } \\
\text { (L/day) }\end{array}$ & $\begin{array}{c}\text { EF } \\
\text { (days/year) }\end{array}$ & $\begin{array}{c}\text { ED } \\
\text { (years) }\end{array}$ & $\begin{array}{c}\text { BW } \\
\text { (kg) }\end{array}$ & $\begin{array}{c}\text { AT } \\
\text { (days) }\end{array}$ \\
\hline Children & 1 & 365 & 70 & 10 & 25,550 \\
\hline Adults & 3 & 365 & 70 & 55 & 25,550 \\
\hline
\end{tabular}
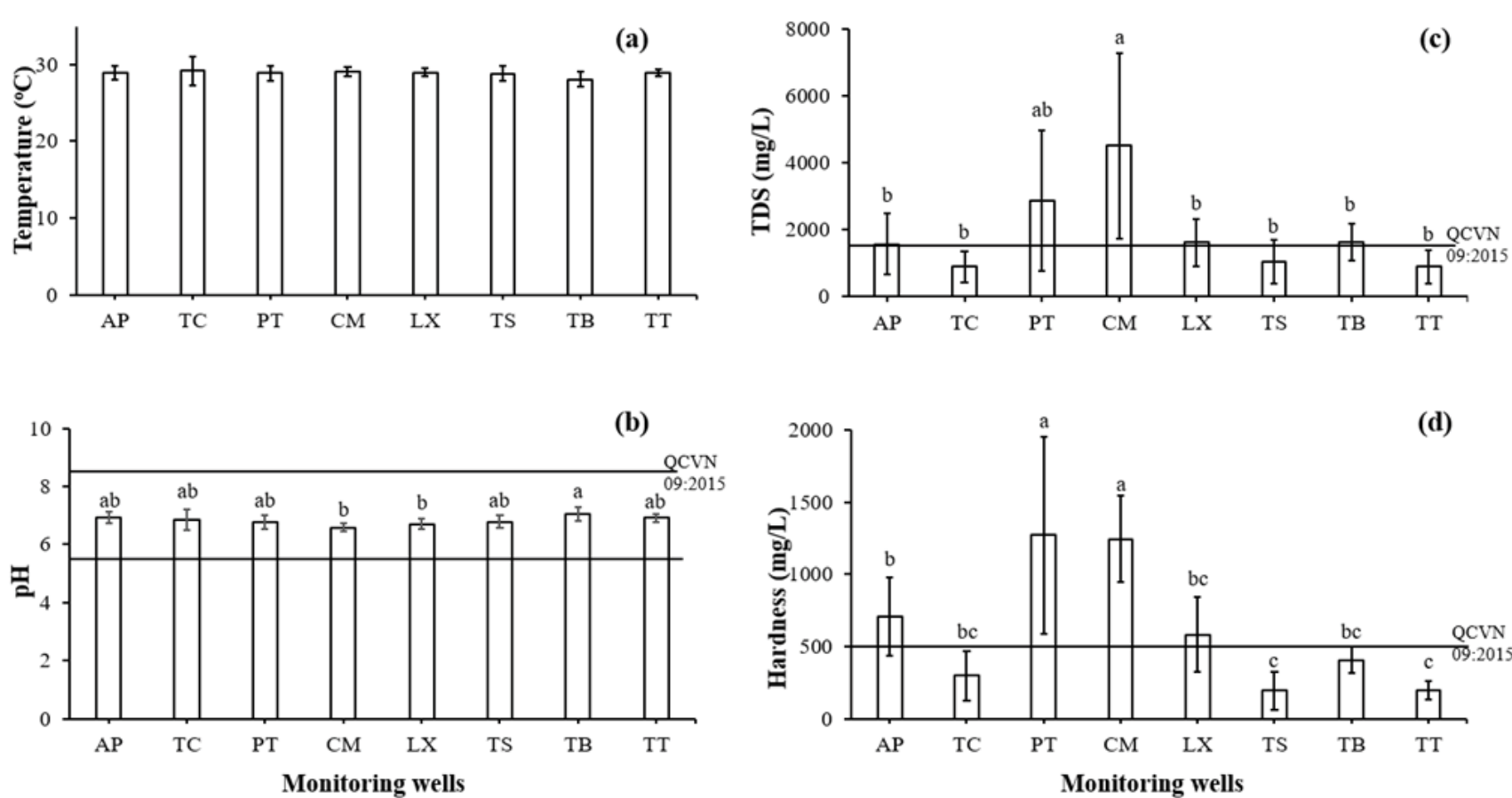

Figure 2 Variation of temperature (a), pH (b), TDS (c) and hardness (d) in groundwater at eight monitoring wells over the period of $2009-2016$ 
accumulated and moved into the groundwater as surface water levels increased and stagnant. This could be a good example of the exchange of water and the transport of pollutants from surface water into the groundwater.

Ammonium $\left(\mathrm{NH}_{4}^{+}-\mathrm{N}\right)$ in groundwater fluctuated between $0.57 \pm$ 0.4 and $5.06 \pm 2.7 \mathrm{mg} / \mathrm{L}$ and there were significant differences between the monitoring wells (Figure 3b). The highest $\mathrm{NH}_{4}^{+}-\mathrm{N}$ concentration was found at Cho Moi station at $5.06 \pm 2.7 \mathrm{mg} / \mathrm{L}$ which was statistically significant difference with the other stations. $\mathrm{NH}_{4}{ }^{+} \mathrm{N}$ concentration in Thoai Son station was the lowest and 8.88 times lower than the $\mathrm{NH}_{4}^{+}-\mathrm{N}$ concentration found in Cho Moi station. At the all monitoring wells, the average $\mathrm{NH}_{4}^{+}-\mathrm{N}$ concentration dry season was $2.3 \pm 1.7 \mathrm{mg} / \mathrm{L}$ and in wet season was $1.9 \pm 1.7 \mathrm{mg} / \mathrm{L}$. Among 8 monitoring wells, there were five wells in An Phu, Tan Chau, Phu Tan, Cho Moi and Tri Ton where the concentration of $\mathrm{NH}_{4}^{+}-\mathrm{N}$ were higher than the permitted standard regulated in QCVN 09-MT:2015/BTNMT $\left(\mathrm{NH}_{4}^{+}-\mathrm{N}<1 \mathrm{mg} / \mathrm{L}\right)$. The occurrence of $\mathrm{NH}_{4}^{+}-\mathrm{N}$ in groundwater indicated the impact of human activities such as poultry, livestock, household waste, septic tanks, and aquaculture. In addition, the use of fertilizers for soil improvement and the supply of nutrients to crops also contributes to the increase in $\mathrm{NH}_{4}^{+}-\mathrm{N}$ concentration in groundwater. This was consistent with the previous discussion that nitrate was also transferred from surface water to groundwater.

The mean Fe concentration in groundwater was presented in (Figure 3c). The highest concentration of total iron $(2.16 \pm 3.36$ $\mathrm{mg} / \mathrm{L}$ ) was found at Thoai Son station and this concentration was statistically significant difference with the remaining monitoring wells $(p<0.05)$. Total Fe found in groundwater at Phu Tan and Tinh Bien stations were relatively low at $0.07 \pm 0.07 \mathrm{mg} / \mathrm{L}$ and $0.07 \pm$ $0.05 \mathrm{mg} / \mathrm{L}$, respectively. There was no significant variation in $\mathrm{Fe}$ concentration in groundwater between the dry and wet seasons. Total iron concentrations at all monitoring wells were within the limit of QCVN 09-MT: 2015/BTNMT (Fe $<5$ mg/L).

Coliforms in groundwater at all monitoring wells were relatively high (693.6 $\pm 543 \mathrm{MPN} / 100 \mathrm{~mL}$ ) (Figure 3d). The highest coliforms were recorded at An Phu and Tinh Bien stations at 1,374.6 $\pm 2,632.5$ MPN/100 mL and 1,212.2 \pm 1,267.2 MPN/100 mL, respectively. The density of coliforms in groundwater monitoring wells did not fluctuate significantly between dry and wet seasons. It is worth noting that coliforms in groundwater samples at all monitoring wells far exceeded the permitted level of QCVN 09-MT: 2015/ BTNMT which permits only $3 \mathrm{MPN} / 100 \mathrm{~mL}$. Prior studies found that groundwater in the Mekong delta was heavily contaminated with coliforms $[5,6]$. Microbial contamination in groundwater is one of the health risks for people who use both surface water and groundwater if the waters are not properly treated.

\section{Arsenic contamination and associated health risk due to groundwater consumption}

Arsenic concentrations have been detected in groundwater in An Giang province. The concentrations of arsenic in An Phu, Tan Chau and Long Xuyen stations were found at $0.3 \pm 0.63 \mathrm{mg} / \mathrm{L}$, $0.54 \pm 1.18 \mathrm{mg} / \mathrm{L}$, and $0.55 \pm 1.21 \mathrm{mg} / \mathrm{L}$, respectively. The arsenic concentrations at all monitoring wells were presented in Table 2. The average arsenic levels tended to increase in the wet season (September). This was in line with previous study reported that the concentration of arsenic in groundwater in the Mekong Delta increased considerably in wet season [7] due to the effect of flooding [8].

Arsenic concentrations at the monitoring wells in Phu Tan, Cho Moi, Thoai Son, Tinh Bien, and Tri Ton were within the allowable limit of QCVN 09-MT: 2015/BTNMT (As $<0.05 \mathrm{mg} / \mathrm{L}$ or $50 \mu \mathrm{g} / \mathrm{L}$ ).
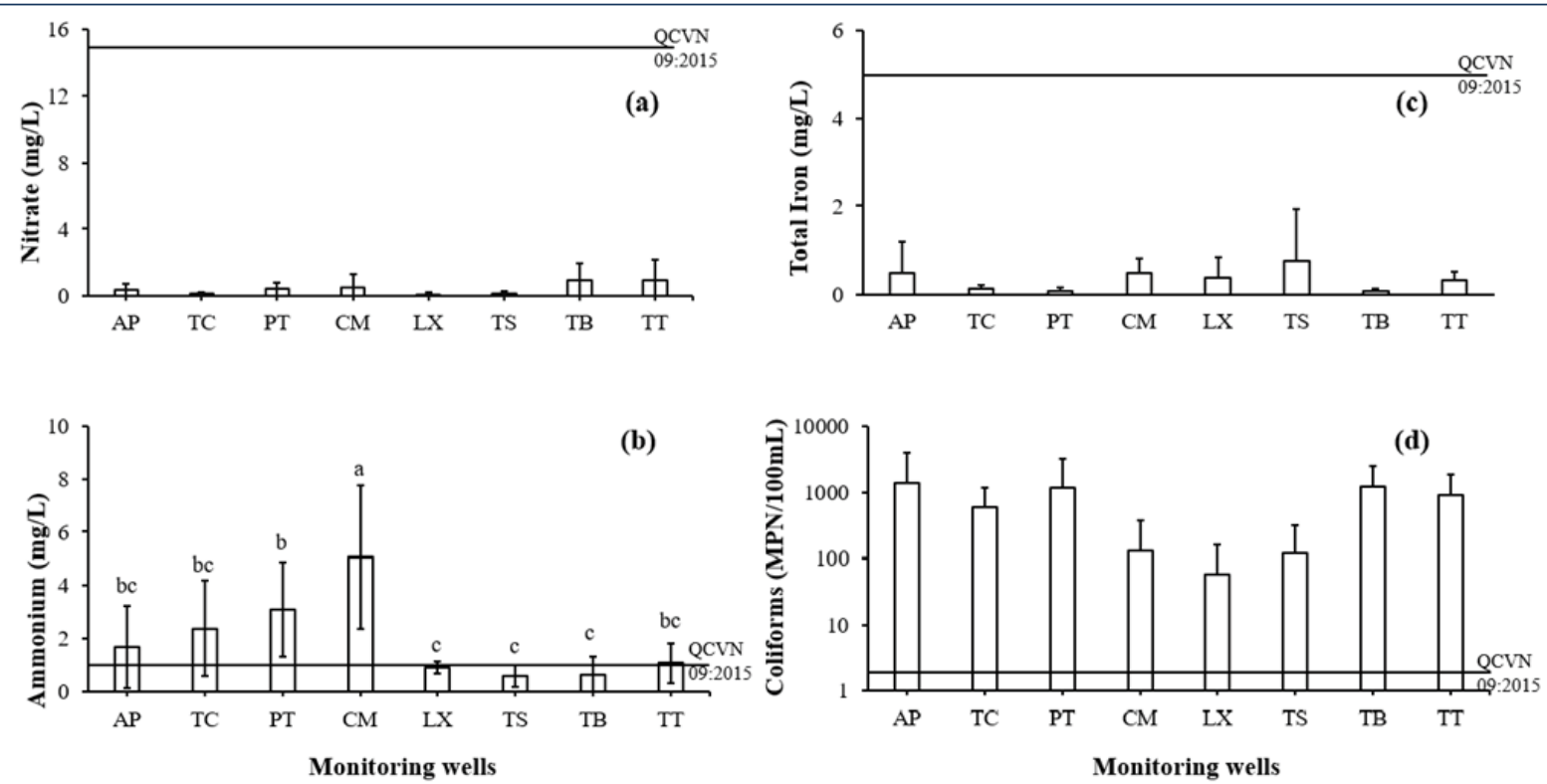

Figure 3 Variation of nitrate (a), ammonium (b), total iron (c) and coliforms (d) in groundwater at eight monitoring wells over the period of $2009-2016$. 
However, the concentration of arsenic in groundwater at An Phu, Tan Chau, and Long Xuyen were 6 times, 10.8 times, 11 times higher than the limit of the arsenic concentration regulated in QCVN 09-MT: 2015/BTNMT. The World Health Organization (WHO) recommends the arsenic level permitted for human consumption (drinking) should be equal or lower than 10 $\mu \mathrm{g} / \mathrm{L}$. This recommended level by $\mathrm{WHO}$ is to reduce health risk associated with using groundwater as drinking water.

The calculated risks for children and adults were greater than acceptable risk level $\left(1 \times 10^{-6}\right)$ which could mean that the cancer risk due to presence of arsenic in groundwater in An Giang province ranged from medium to high. The highest cancer risk for both children and adults occurred in An Phu, Tan Chau and Long Xuyen stations (Table 2), the medium cancer risk associated with groundwater consumption was found in Cho Moi, Thoai Son, and Tri Ton. This study found that children were likely to suffer higher cancer risk than adults, for example, the cancer risk estimation in Table $\mathbf{2}$ indicated that there are likely to have eight children and four adults (in 100 people) at risk of cancer in the Long Xuyen area. In Vietnam, National Technical Regulation on groundwater quality (QCVN 09-MT: 2015/BTNMT) set the acceptable level of arsenic at $50 \mu \mathrm{g} / \mathrm{L}$. This level produced 75 children and 41 adults who have cancer risk in 10,000 people. The World Health Organization's standard limit is $10 \mu \mathrm{g} / \mathrm{L}$ which has contributed to decreasing the risk of cancer for both children and adults [9].

\section{Conclusion}

Based on the assessment of groundwater quality at eight monitoring wells in An Giang province for the period 2009 - 2016 and comparison with QCVN 09-MT: 2015/BTNMT, groundwater has been polluted with TDS, coliforms and arsenic. The levels of coliforms at all monitoring wells were high and exceeded the permitted level while concentrations of arsenic in groundwater at An Phu, Tan Chau and Long Xuyen stations were much higher than the permitted. The cancer risk calculation for both adults and children due to consumption of groundwater contaminated with arsenic indicated that both children and adults were at medium to high cancer risk. Treatment of arsenic in groundwater to bring the cancer risk to one in a million to minimize cancer risk to human health is urgently needed.

Table 2 Health risk associated with using groundwater contaminated by arsenic in an Giang province.

\begin{tabular}{|c|c|c|c|c|c|}
\hline \multirow{2}{*}{ Station } & \multirow{2}{*}{$\begin{array}{c}\text { Concentration of As } \\
(\mu \mathrm{g} / \mathrm{L})\end{array}$} & \multicolumn{2}{|c|}{ CDI (mg/kg.day) } & \multicolumn{2}{|c|}{ Cancer Risk } \\
\hline & & Children & Adults & Children & Adults \\
\hline AP & 300.77 & $3.01 \times 10^{-2}$ & $1.64 \times 10^{-2}$ & $4.51 \times 10^{-2}$ & $2.46 \times 10^{-2}$ \\
\hline $\mathrm{TC}$ & 538.35 & $5.38 \times 10^{-2}$ & $2.94 \times 10^{-2}$ & $8.08 \times 10^{-2}$ & $4.40 \times 10^{-2}$ \\
\hline PT & 13.84 & $1.38 \times 10^{-3}$ & $7.55 \times 10^{-4}$ & $2.08 \times 10^{-3}$ & $1.13 \times 10^{-3}$ \\
\hline $\mathrm{CM}$ & 5.23 & $5.23 \times 10^{-4}$ & $2.85 \times 10^{-4}$ & $7.85 \times 10^{-4}$ & $4.28 \times 10^{-4}$ \\
\hline LX & 550.58 & $5.51 \times 10^{-2}$ & $3.00 \times 10^{-2}$ & $8.26 \times 10^{-2}$ & $4.50 \times 10^{-2}$ \\
\hline TS & 4.82 & $4.82 \times 10^{-4}$ & $2.63 \times 10^{-4}$ & $7.23 \times 10^{-4}$ & $3.94 \times 10^{-4}$ \\
\hline TB & 10.58 & $1.06 \times 10^{-3}$ & $5.77 \times 10^{-4}$ & $1.59 \times 10^{-3}$ & $8.66 \times 10^{-4}$ \\
\hline TT & 4.71 & $4.71 \times 10^{-4}$ & $2.57 \times 10^{-4}$ & $7.07 \times 10^{-4}$ & $3.85 \times 10^{-4}$ \\
\hline QCVN 09-MT:2015/BTNMT & 50 & $5.00 \times 10^{-3}$ & $2.73 \times 10^{-3}$ & $7.50 \times 10^{-3}$ & $4.09 \times 10^{-3}$ \\
\hline WHO & 10 & $1.00 \times 10^{-3}$ & $5.45 \times 10^{-4}$ & $1.50 \times 10^{-3}$ & $8.18 \times 10^{-4}$ \\
\hline
\end{tabular}

\section{References}

1. People's Committee of a Giang province (2015) Report on the state of environment in five years (2011 - 2015) of an Giang province, p: 181.

2. Thu NT (2008) Arsenic pollution in groundwater and health risk assessment for people in Don Duong and Duc Trong district, Lam Dong province. Bachelor thesis, Da Lat University.

3. Mai NTP, Hue NT, Thao NTP (2014) Assessment of arsenic accumulation level in hair and nails of residents living in region of multi - metal ore exploitation in Nui Phao, Thai Nguyen. J Chem Phys Biol Anal 19: 21-26.

4. Quang NH (2014) Health risk assessment for arsenic pollution in groundwater in Ho Chi Minh City. VNU J Sci Earth Environ Sci 30: 50-57.
5. Sanh NV, Son NN, Tuan VV, Khoi LD (2010) Research on water resources in Tra Vinh: Current status of exploitation, use and solutions for sustainable use management. Can Tho University J Sci 15b: 167-177.

6. Hoa VT (2016) Evaluation of management activities and quality of rural water supply from groundwater in Tien Giang province. Bachelor thesis. Can Tho university.

7. Lap NV (2005) Status of arsenic pollution in ground water of Tan Hong district, Dong Thap province. Provincial research project report.

8. Berg M, Tran HC, Nguyen TC, Pham HV, Schertenleib R, et al. (2001) Arsenic contamination of groundwater and drinking water in Vietnam: a human health threat. Environ Sci Technol 35: 2621-2626.

9. https://cfpub.epa.gov/ncea/iris2/chemicalLanding.cfm?substance $n m b r=278$ 